\title{
Recent observations of critically endangered North Pacific right whales (Eubalaena japonica) off the west coast of Canada
}

\author{
John K. B. Ford ${ }^{1 *}$, James F. Pilkington ${ }^{1}$, Brian Gisborne ${ }^{1}$, Timothy R. Frasier², Robin M. Abernethy ${ }^{1}$ \\ and Graeme M. Ellis ${ }^{1}$
}

\begin{abstract}
Background: The eastern North Pacific population of right whale (Eubalaena japonica) is considered to be one of the smallest whale populations in the world and is at serious risk of extirpation. During the past century, there have been only six records of North Pacific right whales off the west coast of Canada. All six were taken by whaling operations, the last in 1951.

Results: Two independent and extremely rare sightings of North Pacific right whales were made off the coast of British Columbia, Canada, in 2013. We describe observations made of these two whales and include information on prey and genetic identity for one individual.

Conclusions: These sightings represent the first time this species has been confirmed in Canadian waters in 62 years, and likely the only time in the last 15 years that the species has been sighted south of the Kodiak Island area, Alaska, in the eastern North Pacific Ocean. It can be concluded that, although extremely rare, the species has not been extirpated from waters off Canada's Pacific coast.
\end{abstract}

Keywords: Neocalanus plumchrus, British Columbia, Eubalaena japonica, North Pacific right whale

\section{Background}

The North Pacific right whale (Eubalaena japonica) is one of the most endangered whale species in the world, possibly having an abundance of only 500 individuals (Reilly et al. 2008; National Marine Fisheries Service (NMFS) 2013). Once common in many areas of the North Pacific and Bering Sea, the species was severely depleted by intensive whaling in the mid 19th century (Brownell et al. 2001; Scarff 2001; Josephson et al. 2008). Although numbers may have been increasing by the mid 20th century following international protection in 1935 (Brownell et al. 2001), large illegal and unreported catches by Soviet whalers in the 1960s likely reversed

\footnotetext{
* Correspondence: john.k.ford@dfo-mpo.gc.ca

'Fisheries and Oceans Canada, Pacific Biological Station, 3190 Hammond Bay Rd, Nanaimo, BC V9T 6N7, Canada

Full list of author information is available at the end of the article
}

any nascent recovery and the species remains endangered today (Ivashchenko and Clapham 2012).

Historical whaling data from 19th century whaling catches suggest that the North Pacific right whale is divided into discrete western and eastern populations (Brownell et al. 2001; Clapham et al. 2004; Shelden et al. 2005; Gregr 2011; NMFS 2013). During summer, the western population was found mostly in the Sea of Okhotsk, the Sea of Japan, and off the coasts of the Kuril Islands and Kamchatka. The eastern population was concentrated in summer in the southeastern Bering Sea (the "Bristol Bay Ground") and in the Gulf of Alaska, primarily north of $50^{\circ} \mathrm{N}$ latitude (the "Northwest Ground"). In waters off western Canada, right whales were taken mostly to the west of Haida Gwaii (formerly Queen Charlotte Islands), north of $52^{\circ} \mathrm{N}$ latitude, from May to August (Townsend 1935; Shelden et al. 2005). North Pacific right whales generally moved northward as summer progressed and 
southward in fall, but any migratory patterns are poorly defined and potential winter grounds are unknown (Scarff 1986; Brownell et al. 2001).

Both North Pacific right whale populations are at serious risk of extirpation, especially the eastern population (Reilly et al. 2008; LeDuc et al. 2012). There is no current abundance estimate for the western North Pacific population but sightings - though uncommon - occur regularly (Brownell et al. 2001; Reilly et al. 2008; Sekiguchi et al. 2014; Matsuoka et al. 2014). In contrast, the eastern North Pacific population has been estimated at fewer than 50 animals using multiple independent techniques (Wade et al. 2011b; Marques et al. 2011; LeDuc et al. 2012). Once widely distributed in the Gulf of Alaska, around the Aleutian Islands and in the eastern Bering Sea, most recent sightings and acoustic detections of eastern North Pacific right whales have been confined to an area within the southeastern Bering Sea (LeDuc et al. 2001; Shelden et al. 2005; Wade et al. 2006, 2011a; Munger et al. 2008; Marques et al. 2011). Animals have been regularly detected in this area during visual and acoustic surveys since 1996, and it has been designated as critical habitat in the US (NMFS 2013). Mark-recapture modeling using photoidentifications and genetic samples from this area resulted in an estimate of 31 individuals (Wade et al. 2011b).

South of the Bering Sea, sightings of eastern North Pacific right whales are extremely rare in recent decades. There have been only six documented sightings in the northern Gulf of Alaska since the 1960s, all in the Albatross Bank area south of Kodiak Island (Waite et al. 2003; Wade et al. 2011b), an area that has also been designated as critical habitat in the US (NMFS 2013). It is unclear whether the Gulf of Alaska and Bering Sea animals represent a single or multiple populations (LeDuc et al. 2012). Only seven reliable sighting records exist for eastern North Pacific waters offshore of Baja California to Washington State since 1990, and none since 1998 (Waite et al. 2003; J. Scarff, pers. comm. 2015). Off the coast of Canada, the last confirmed record of a North Pacific right whale was a mature male killed by whalers, apparently in error, off Vancouver Island, British Columbia, in 1951 (Pike and MacAskie 1969; Ford 2014).

Here, we describe two independent encounters with North Pacific right whales that we documented in 2013 off the west coast of Canada. These represent the first time this species has been confirmed in Canadian waters in 62 years, and likely the only time in the last 15 years that right whales have been found south of the Kodiak Island area, Alaska, in the eastern North Pacific (Waite et al. 2003; J. Scarff, pers. comm. 2015). We also describe the feeding behaviour and prey of one of these two animals, as well as the results of genetic analyses of a tissue sample taken from this same individual.

\section{Methods \\ Survey effort}

Since 2002, the Cetacean Research Program (CRP) at the Pacific Biological Station (Fisheries and Oceans Canada, Nanaimo, British Columbia), has conducted annual multispecies cetacean surveys from large-vessel platforms over continental shelf and off-shelf waters throughout Canada's Pacific Exclusive Economic Zone. In total, these surveys have amounted to over $60,000 \mathrm{~km}$ of linear on-effort track lines. Details of survey methodology are provided in Ford et al. (2010). Several tens of thousands $\mathrm{km}$ of small-vessel survey effort has also been expended annually in nearshore waters along the coast of British Columbia (up to $50 \mathrm{~km}$ offshore) as part of long-term studies of killer whales (Orcinus orca). In addition to these vessel surveys, systematic aerial surveys for cetaceans were undertaken during 2012-2014 off the west coast of Vancouver Island to approximately $200 \mathrm{~km}$ offshore. Surveys were flown at an altitude of $305 \mathrm{~m}(1000 \mathrm{ft})$ and speed of $278 \mathrm{~km} \mathrm{hr}^{-1}$ (150 knots) and totalled about 22,000 km of survey effort. The two encounters reported here are the only North Pacific right whales seen during these combined efforts.

\section{Field observation and data collection}

When encountered, the whales were approached to a distance of $25 \mathrm{~m}$ and digital images were taken of both sides of the animals' head for individual photoidentification. These were submitted to a photo-ID catalogue for the species maintained at the Marine Mammal Laboratory (MML) (NOAA, Seattle, WA). During the first of the two encounters, the individual appeared to be actively feeding at the surface (see Results). Samples of zooplankton prey and a scat sample were collected using a fine-mesh dip net deployed from a small skiff travelling in the whale's wake. A sample of skin and blubber was collected from this individual using a small biopsy dart deployed from a dart projector (see Barrett-Lennard et al. (1996) for details).

\section{Genetic analysis}

The skin sample obtained from the first of the two North Pacific right whales was used for genetic analyses to determine the whale's sex and mitochondrial haplotype composition. Sex was determined based on polymerase chain reaction (PCR) amplification using the primers described in Gilson et al. (1998) that amplify a $\sim 400 \mathrm{bp}$ fragment of the X-chromosome, and a $\sim 200$ bp fragment of the Y-chromosome. PCR products were size-separated and visualized on a $1.5 \%$ agarose gel stained with ethidium bromide. A $~ 400$ base pair portion 
of the mitochondrial control region was amplified using the primers t-Pro and Primer-2 described in Yoshida et al. (2001). The resulting fragments were then sequenced in both directions. A BLAST (Basic Local Alignment Search Tool) search (Altschul et al. 1990) confirmed the species, with the top eight "hits" all being Eubalaena japonica. To compare the sequences of this animal to other Eubalaena samples, control region sequences available on GenBank were downloaded. These amounted to 9 E. japonica sequences, 166 Southern right whale (E. australis) sequences, and 6 North Atlantic right whale (E. glacialis) sequences. All sequences were aligned using Clustal X (Thompson et al. 1994), to identify variable sites and categorize each sequence. Duplicate sequences were identified and removed using FaBox (Villesen 2007). Phylogenetic analyses were conducted using MrBayes (Ronquist et al. 2012), and the final tree was visualized using FigTree.

\section{Results}

Encounter 1: 9-13 June 2013

The first sighting in 2013 was made on 9 June by JFP during a whale survey aboard the Canadian Coast Guard Ship (CCGS) Arrow Post. The sighting was of a single whale on the continental shelf slope approximately $15 \mathrm{~km}$ off the northwest coast of Haida Gwaii between Port Louis and Frederick Island ( $53^{\circ} 37.5^{\prime} \mathrm{N}, 133^{\circ} 17.2^{\prime} \mathrm{W}$; Fig. 1). The animal was subsequently re-located on 12 June and again on 13 June within $20 \mathrm{~km}$ of the original sighting location, still on the shelf slope. JKBF and GME joined the ship for observations on 13 June. We spent a total of $17 \mathrm{~h}$ observing the animal over the 3 days, which allowed for documentation of behaviour as well as the collection of identification photos, tissue biopsy, and prey and scat samples. Genetic analyses of the tissue sample revealed that the whale was a female. She was estimated to be 10$11 \mathrm{~m}$ in length, thus a subadult (Omura 1958; Omura et al. 1969). Photo-identification images were obtained for both

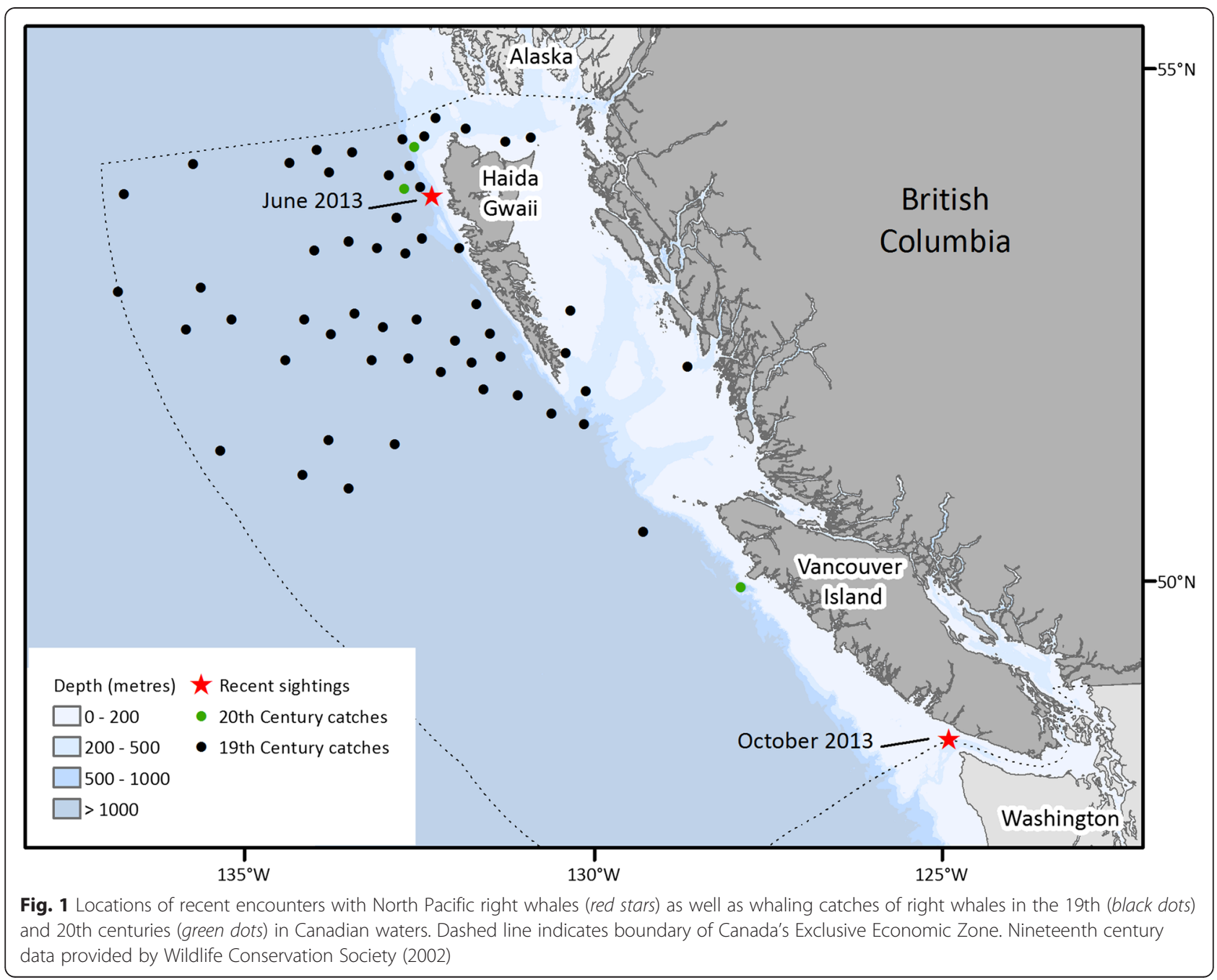


sides of the whale's body (Fig. 2a). Callosity and scar patterns did not match any of the 22 distinct individuals in the MML's North Pacific right whale catalogue, and the whale has been assigned the new identifier MML90 (A. Kennedy, MML, pers. comm. 2014).

Each day, the whale's predominant behaviour was feeding on visibly dense aggregations of zooplankton prey at the surface. On 9 June, it was feeding over the steep continental slope with bottom depths of about $450 \mathrm{~m}$. On 12 and 13 June, it was feeding over shallower parts of the slope with bottom depths of $150-250 \mathrm{~m}$. On 2 days, small samples of prey were collected at the surface using a fine-meshed net about $30 \mathrm{~m}$ behind the feeding whale. These were identified as late-stage copepods Neocalanus plumchrus (C5: $n=13$; C4: $n=1)$. A
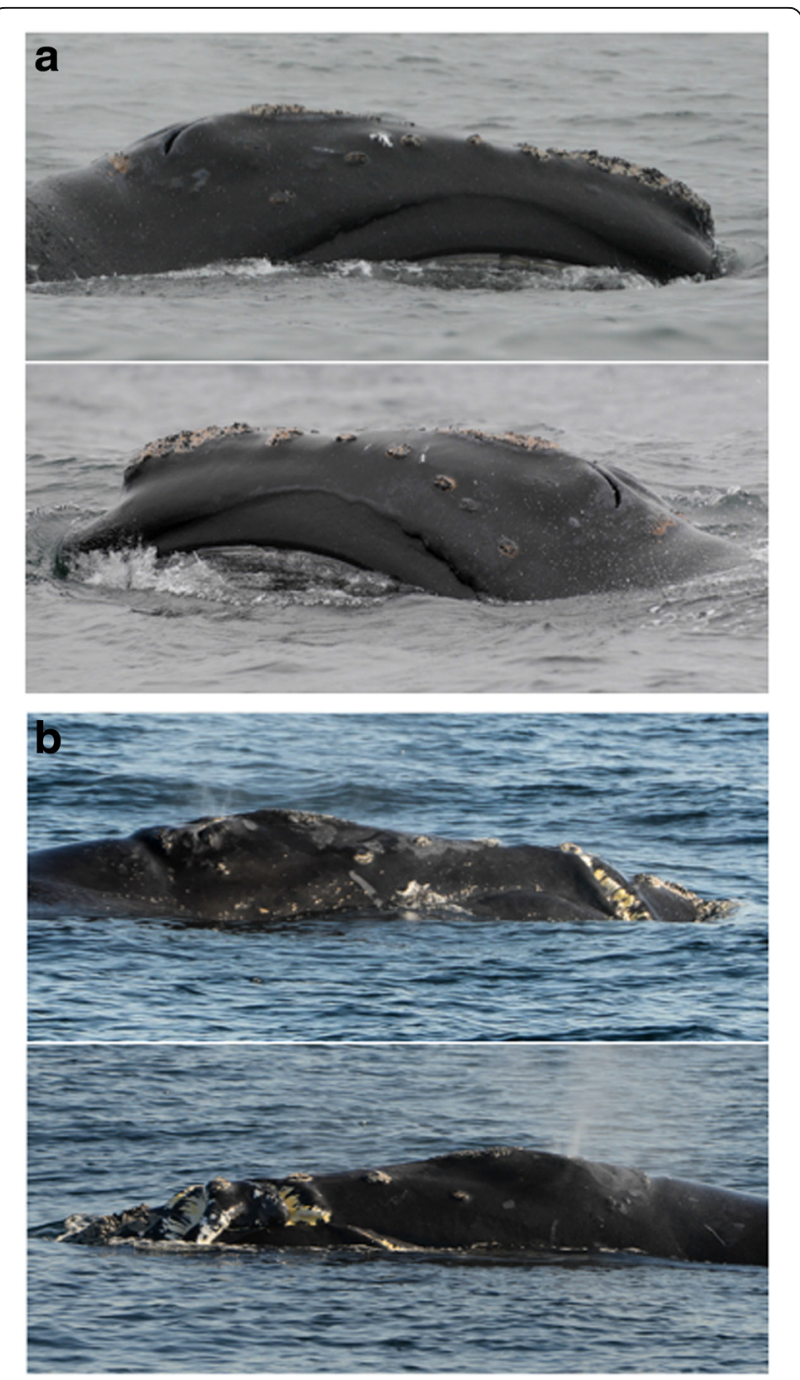

Fig. 2 Photo-identification images of the right (top) and left (bottom) sides of the head of the North Pacific right whales encountered on 9-13 June 2013 (a) and 25-26 October 2013 (b). (Photos by authors GME (A, top), JFP (A, bottom), and JKBF (B, top and bottom) sample of scat that was also collected at the surface awaits visual and genetic identification of prey species.

Mitochondrial sequence analysis confirmed that the whale was an E. japonica (Fig. 3) but revealed that it had a haplotype that was distinct from those yet reported for this species on GenBank (Table 1). However, the differences were slight, with the new sequence differing from two known sequences by a single transition (Table 1).

\section{Encounter 2: 25-26 October 2013}

The second sighting was made on the evening of 25 October 2013, at Swiftsure Bank about $15 \mathrm{~km}$ off the southwest coast of Vancouver Island $\left(48^{\circ} 31.04^{\prime} \mathrm{N}, 124^{\circ} 52.3^{\prime}\right.$ W; Fig. 1), by BG. The animal was found amidst an aggregation of about 8 humpback whales (Megaptera novaeangliae), and appeared to be socializing with them at the surface. Associations with humpbacks have been noted in other sightings in the Gulf of Alaska and Hawaii (Herman et al. 1980; Rowntree et al. 1980; Waite et al. 2003; Wade et al. 2011a, b). The following day, BG was joined by JKBF, GME and RMA and the animal was re-located in the same area on Swiftsure Bank. The right whale was travelling in association with two humpback whales. It was estimated to be at least $15 \mathrm{~m}$ in length, and thus probably sexually mature (Omura 1958; Omura et al. 1969). No genetic sample was obtained so sex could not be determined. Approximately $8 \mathrm{~h}$ were spent observing and photographing the whale over the 2 days. No surface feeding was documented during this encounter, though occasional feeding at depth could not be ruled out. Water depths in the area were $100-150 \mathrm{~m}$. Identification photographs of the animal were collected (Fig. 2b), which confirmed that this was a different individual from the animal sighted in June. This animal had a distinctive healed wound that extended from its lower left jaw over its rostrum, where the tissue had once been deeply incised. It is probable that this wound, and scars evident on the animal's dorsal surface and caudal peduncle, resulted from a past entanglement in fishing gear (Kraus 1990). As with the first animal, photoidentification images did not match any individual in the MML's North Pacific right whale catalogue, and it has been assigned the new identifier MML92 (A. Kennedy, MML, pers. comm. 2014).

\section{Discussion}

Our sightings of these two North Pacific right whales are the first confirmed records of the species in Canadian waters since 1951. There was a report of two right whales in the Swiftsure Bank area in August 1983 (Reeves and Leatherwood 1985), but the very brief sighting (one surfacing at $200 \mathrm{~m}$ distance) was made in rough sea conditions and species identification is questionable (Ford 2014). Two North Pacific right whales were reported off Canada's 


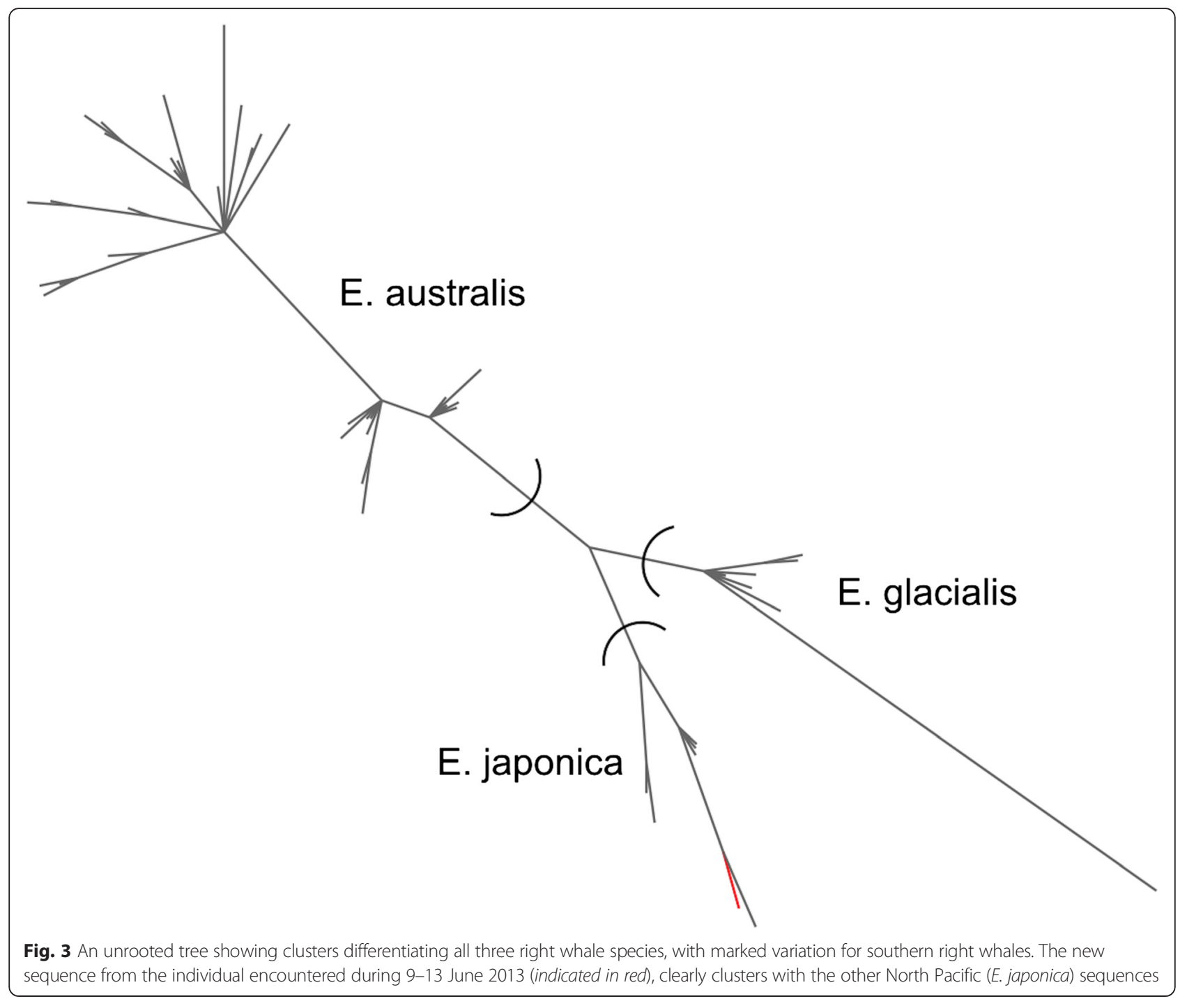

Table 1 E. japonica sequences available from GenBank, aligned to be the same length as the new sequence, with variable sites shown

\begin{tabular}{|c|c|c|c|c|c|c|c|c|c|c|c|c|c|c|c|c|c|c|c|}
\hline \multirow[b]{2}{*}{ Accession \# } & \multirow[b]{2}{*}{ Reference } & \multicolumn{18}{|c|}{ Variable Sites } \\
\hline & & 184 & 239 & 246 & 255 & 256 & 260 & 264 & 271 & 286 & 348 & 366 & 388 & 406 & 445 & 446 & 452 & 473 & 514 \\
\hline$J X 441361.1$ & LeDuc et al. (2012) & G & C & C & G & $\mathrm{T}$ & C & A & G & $\mathrm{T}$ & A & $\mathrm{T}$ & $\mathrm{T}$ & A & C & C & C & G & C \\
\hline$J X 441360.1$ & LeDuc et al. (2012) & G & C & C & G & $\mathrm{T}$ & C & A & G & $\mathrm{T}$ & A & C & $\mathrm{T}$ & A & C & C & C & G & C \\
\hline$J X 441362.1$ & LeDuc et al. (2012) & A & C & C & G & $\mathrm{T}$ & C & G & G & $\mathrm{T}$ & A & $\mathrm{T}$ & $\mathrm{T}$ & A & C & C & $\mathrm{T}$ & G & $\mathrm{T}$ \\
\hline JX441357.1 & LeDuc et al. (2012) & G & $\mathrm{T}$ & C & G & $\mathrm{T}$ & $\mathrm{T}$ & G & G & $\mathrm{T}$ & G & $\mathrm{T}$ & C & G & $\mathrm{T}$ & $\mathrm{T}$ & $\mathrm{T}$ & A & C \\
\hline JX441356.1 & LeDuc et al. (2012) & G & $T$ & C & G & $\mathrm{T}$ & $\mathrm{T}$ & A & G & $\mathrm{T}$ & G & $\mathrm{T}$ & C & A & C & $\mathrm{T}$ & $\mathrm{T}$ & A & C \\
\hline JX441358.1 & LeDuc et al. (2012) & G & C & C & $A$ & C & $\mathrm{T}$ & G & A & $\mathrm{T}$ & A & C & $\mathrm{T}$ & A & C & $\mathrm{T}$ & $\mathrm{T}$ & G & C \\
\hline$J X 441360.1$ & LeDuc et al. (2012) & G & $\mathrm{T}$ & $\mathrm{T}$ & G & C & $\mathrm{T}$ & G & A & C & A & C & $\mathrm{T}$ & A & C & C & C & G & C \\
\hline New & & G & C & C & A & $C$ & $\mathrm{~T}$ & G & A & $\mathrm{T}$ & A & C & $\mathrm{T}$ & A & C & $\mathrm{T}$ & $\mathrm{T}$ & G & $\mathrm{T}$ \\
\hline NC_006931.1 & Sasaki et al. (2005) & G & C & C & A & C & $\mathrm{T}$ & G & A & $\mathrm{T}$ & A & C & $\mathrm{T}$ & A & C & $\mathrm{T}$ & $\mathrm{T}$ & G & C \\
\hline AP006474.1 & Sasaki et al. (2005) & G & C & C & A & C & $\mathrm{T}$ & G & A & $\mathrm{T}$ & A & C & $\mathrm{T}$ & A & C & $\mathrm{T}$ & $\mathrm{T}$ & G & C \\
\hline
\end{tabular}

The new sequence differs from a few others (AP006474.1, JX441358.1, and NC_006931.1) at only a single position (514). Sequences AP006474.1, JX441358.1, and NC_006931.1 are all the same at the sites shown, but all are longer than shown here, but have been trimmed to make comparable to the new sequence. Thus, they may differ at sites not shown 
west coast in 1970 by a Japanese scouting vessel (see Table 2.2 in Brownell et al. 2001), but the location provided is so general it is not clear if the animals were even within Canadian waters. Prior to our two sightings, there are only six records of North Pacific right whales off the coast of British Columbia during the past century, and all were killed by whalers (Ford 2014). Five of these were west or north of Haida Gwaii, and the sixth was close to the northwest coast of Vancouver Island (Fig. 1).

The location of the June 2013 sighting off Haida Gwaii is within an area where numerous right whales were taken by whalers in the 19th and early 20th centuries, mostly during the months of May to July (Fig. 1). This area has been predicted to be highly suitable early summer habitat for North Pacific right whales (Gregr 2011), and the vigorous feeding behaviour exhibited by this whale over the 3 days of observation is consistent with this prediction. The whale was feeding at the surface on the large calanoid copepod N. plumchrus (C5 stage), the same species that has been found in the stomachs of North Pacific right whales killed south of Kodiak Island (Omura et al. 1969). Wade et al. (2011a) also noted this copepod among other zooplankton species in an area where right whales were seen on Albatross Bank south of Kodiak Island.

The waters off southwest Vancouver Island where the second right whale was observed in October 2013 is not an area where this species was hunted during the commercial whaling period, but it is within its range (Scarff 1986; Brownell et al. 2001). Bones of North Pacific right whales have been identified in archaeological sites on the northwest coast of Washington State (Scarff 1986) and on southwestern Vancouver Island (Arndt 2011), indicating either hunted or stranded animals were utilized at least occasionally by aboriginal people in the region. There was also a confirmed sighting of a single right whale on 24 May 1992 over Quinault Canyon, which is off the Washington coast approximately $150 \mathrm{~km}$ south of the location of our October 2013 sighting on Swiftsure Bank (Rowlett et al. 1994). Interestingly, Širović et al. (2015) recently detected two presumed right whale "up-calls" in recordings made on 29 June 2013 by an autonomous acoustic recorder deployed at Quinault Canyon.

\section{Conclusions}

After a period of over half a century without a confirmed sighting of North Pacific right whales off the west coast of Canada, it was uncertain whether the species should be considered extant in this region. These two confirmed sightings in 2013 confirm that the species has not been extirpated from these waters. It is somewhat surprising that these two sightings were made in the same year. Densities of calanoid copepods off the coast were reported to be average during the summer of 2013 (Batten 2014; Galbraith et al. 2014), so it seems unlikely that the whales were attracted to the region by unusually favourable feeding conditions. The sightings of these two exceedingly rare animals were more than 4 months and $850 \mathrm{~km}$ apart, so it is not clear that they were connected in any way.

\section{Abbreviations}

CCGS, Canadian coast guard ship; CRP, Cetacean research program; MML, Marine mammal laboratory; NMFS, National marine fisheries service; NOAA, National oceanic and atmospheric administration; PCR, polymerase chain reaction

\section{Acknowledgements}

We thank the officers and crew of the CCGS Arrow Post and staff of Langara Fishing Lodge for facilitating the sighting and data collection in June 2013. Amy Kennedy kindly compared our photo-identification images with those in the North Pacific right whale catalogue maintained at the Marine Mammal Laboratory, and assigned new identification numbers for the two individuals we observed. We thank Moira Galbraith for identification of the copepods we collected from the feeding right whale. We are also grateful to Moira Brown, Bob Brownell, Phil Clapham, Phil Hamilton, and Amy Knowlton for their comments on the likely cause of wounds on the October 2013 whale, and Jim Scarff for information on right whale sightings south of $50^{\circ} \mathrm{N}$ latitude. Gillian Woolmer and Ed Gregr provided access to whale catch data digitized from charts in Townsend (1935). Phil Clapham and Randall Reeves provided helpful comments on an earlier draft of this paper.

\section{Funding}

Field work and analyses were funded by the Species at Risk Program of Fisheries and Oceans Canada.

\section{Authors' contributions}

JKBF, JFP, BG, RMA, and GME participated in field data collection and TRF conducted the genetic analyses. JKBF, JFP and TRF wrote the manuscript with contributions from RMA and GME. JKBF, TRF and RMA prepared the figures. All authors read and approved the final manuscript.

\section{Competing interests}

The authors declare that they have no competing interests.

\section{Ethics approval and consent to participate}

This study was conducted under Fisheries and Oceans Canada's research licence MML-001. Field sampling procedures were approved by Fisheries and Oceans Canada's Pacific Region Animal Care Committee under protocol 12-008R1.

\section{Author details}

${ }^{1}$ Fisheries and Oceans Canada, Pacific Biological Station, 3190 Hammond Bay Rd, Nanaimo, BC V9T 6N7, Canada. ${ }^{2}$ Department of Biology, Saint Mary's University, 923 Robbie St, Halifax, Nova Scotia B3H 3C3, Canada.

Received: 29 May 2016 Accepted: 3 June 2016

Published online: 06 July 2016

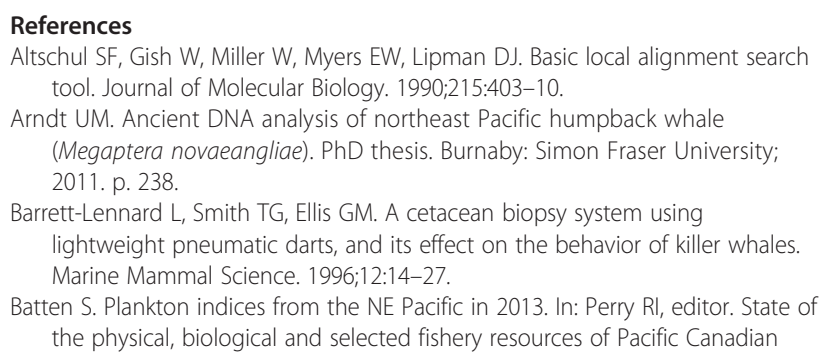
lightweight pneumatic darts, and its effect on the behavior of killer whales. Marine Mammal Science. 1996;12:14-27.

Batten S. Plankton indices from the NE Pacific in 2013. In: Perry Rl, editor. State of the physical, biological and selected fishery resources of Pacific Canadian 
marine ecosystems in 2013, Canadian Technical Report of Fisheries and Aquatic Science, vol. 3102. 2014. p. 34-6.

Brownell Jr RL, Clapham PJ, Miyashita T, Kasuya T. Conservation status of North Pacific right whales. Journal of Cetacean Research and Management Specia Issue. 2001;2:269-86.

Clapham PJ, Good C, Quinn SE, Reeves RR, Scarff JR, Brownell Jr RL. Distribution of North Pacific right whales (Eubalaena japonica) as shown by 19th and 20th century whaling catch and sighting records. Journal of Cetacean Research and Management. 2004;6:1-6.

Ford JKB. Marine Mammals of British Columbia, Royal BC museum handbook, mammals of BC, vol. 6. Victoria: Royal BC Museum; 2014. p. 460.

Ford JKB, Abernethy RM, Phillips AV, Calambokidis J, Ellis GM, Nichol LM. Distribution and relative abundance of cetaceans in western Canadian waters from ship surveys, 2002-2008. Canadian technical report of fisheries and aquatic science. 2010. p. 51.

Galbraith M, Mackas D, Young K. Zooplankton along the BC continental margin: a near-average year. In: Perry Rl, editor. State of the physical, biological and selected fishery resources of Pacific Canadian marine ecosystems in 2013, Canadian Technical Report of Fisheries and Aquatic Science, vol. 3102. 2014. p. 52-8.

Gilson A, Syvanen M, Levine K, Banks J. Deer gender determination by polymerase chain reaction: validation study and application to tissues, bloodstains, and hair forensic samples from California. California Fish and Game. 1998;84:159-69.

Gregr EJ. Insights into North Pacific right whale Eubalaena japonica habitat from historic whaling records. Endangered Species Research. 2011;15:223-39.

Herman LM, Baker CS, Forestall PH, Antinoja RC. Right whale Balaena glacialis sightings near Hawaii: a clue to the wintering grounds? Marine Ecology Progress Series. 1980;2:271-5.

Ivashchenko YV, Clapham PJ. Soviet catches of right whales Eubalaena japonica and bowhead whales Balaena mysticetus in the North Pacific ocean and the Okhotsk Sea. Endangered Species Research. 2012;18:201-17.

Josephson E, Smith TD, Reeves RR. Historical distribution of right whales in the North Pacific. Fish and Fisheries. 2008;9:155-68.

Kraus SD. Rates and potential causes of mortality in North Atlantic right whales (Eubalaena glacialis). Marine Mammal Science. 1990;6:278-91.

LeDuc RG, Perryman WL, Gilpatrick JW, Hyde J, Stinchcomb C, Carretta JV, et al. A note on recent surveys for right whales in the southeastern Bering Sea. Journal of Cetacean Research and Management. 2001;2:287-9.

LeDuc RG, Taylor BL, Martien KK, Robertson KM, Pitman RL, Salinas JC, et al. Genetic analysis of right whales in the eastern North Pacific confirms severe extirpation risk. Endangered Species Research. 2012;18:163-7.

Marques TA, Munger L, Thomas L, Wiggins S, Hildebrand JA. Estimating North Pacific right whale Eubalaena japonica density using passive acoustic cue counting. Endangered Species Research. 2011;13:163-72.

Matsuoka K., Hakamada T. and Miyashita T. Recent sightings of the North Pacific right (Eubalaena japonica) whales in the western North Pacific based on JARPN and JARPN II surveys (1994 to 2013). Unpublished paper to the IWC Scientific Committee, Bled, Slovenia; 2014. (12-24 May 2014, paper SC/65b/BRG11).

Munger LM, Wiggins SM, Moore SE, Hildebrand JA. North Pacific right whale (Eubalaena japonica) seasonal and diel calling patterns from long-term acoustic recordings in the southeastern Bering Sea, 2000-2006. Marine Mammal Science. 2008;24(4):795-814.

National Marine Fisheries Service (NMFS). Final Recovery Plan for the North Pacific Right Whale (Eubalaena japonica). National Marine Fisheries Service, Office of Protected Resources. Silver Spring, Maryland; 2013.

Omura H. North Pacific right whale. Scientific Reports of the Whales Research Institute. 1958;13:1-52.

Omura H, Ohsumi S, Nemoto T, Nasu K, Kasuya T. Black right whales in the North Pacific. Scientific Reports of the Whales Research Institute. 1969;21:1-78

Pike GC, MacAskie IB. Marine mammals of British Columbia. Bulletin of the Fisheries Research Board of Canada. 1969;71:1-54.

Reeves RR and Leatherwood S. Sightings of right whales (Eubalaena glacialis) in the eastern North Pacific. Unpublished paper to the International Whaling Commission, Bournemouth, UK; 1985.(June 1985, paper SC/37/PS3).

Reilly SB, Bannister JL, Best PB, Brown M, Brownell Jr. RL, Butterworth DS, Clapham PJ, Cooke J, Donovan GP, Urbán J and Zerbini AN (2008) Eubalaena japonica. The IUCN Red List of Threatened Species. Version 2014.3. <wwW. iucnredlist.org >. Downloaded on 16 Dec 2014

Ronquist F, Teslenko M, van der Mark P, Ayres DL, Darling A, Höhna S, et al. MrBayes 3,2: efficient Bayesian phylogenetic inference and model choice across a large model space. Systematic Biology. 2012;61:539-42.
Rowlett RA, Green GA, Bowlby CE, Smultea MA. The first photographic documentation of a northern right whale off Washington State. Northwestern Naturalist. 1994;75: $102-4$.

Rowntree V, Darling J, Silber G, Ferrari M. Rare sighting of a right whale (Eubalaena glacialis) in Hawaii. Canadian Journal of Zoology. 1980;58:309-12.

Sasaki T, Nikaido M, Hamilton H, Goto M, Kato H, Kanda N, et al. Mitochondrial phylogenetics and evolution of mysticete whales. Systematic Biology. 2005;54:77-90.

Scarff JE. Historic and present distribution of the right whale (Eubalaena glacialis) in the eastern North Pacific south of $50^{\circ} \mathrm{N}$ and east of $180^{\circ} \mathrm{W}$. Report of the International Whaling Commission. 1986;10:43-63.

Scarff JE. Preliminary estimates of whaling-induced mortality in the 19th century North Pacific right whale (Eubalaena japonicus) fishery, adjusting for struckbut-lost whales and non-American whaling. Journal of Cetacean Research and Management, Special Issue. 2001;2:261-8.

Sekiguchi K, Onishi H, Sasaki H, Haba S, Iwahara Y, Mizuguchi D, et al. Sightings of the western stock of North Pacific right whales (Eubalaena japonica) in the far southeast of the Kamchatka Peninsula. Marine Mammal Science. 2014;30: 1199-209.

Shelden KEW, Moore SE, Waite JM, Wade PR, Rugh DJ. Historic and current habitat use by North Pacific right whales Eubalaena japonica in the Bering Sea and Gulf of Alaska. Mammal Review. 2005;35:129-55.

Širović A, Johnson SC, Roche LK, Varga LM, Wiggins SM, Hildebrand JA. North Pacific right whales (Eubalaena japonica) recorded in the Northeastern Pacific Ocean in 2013. Marine Mammal Science. 2015:31:800-7.

Thompson JD, Higgins DG, Gibson TJ. CLUSTAL W: improving the sensitivity of progressive multiple sequence alignment through sequence weighting, position-specific gap penalties and weight matrix choice. Nucleic Acids Research. 1994;22:4673-80.

Townsend $\mathrm{CH}$. The distribution of certain whales as shown by logbook records of American whaleships. Zoologica. 1935;19:1-50.

Villesen P. FaBox: an online toolbox for fasta sequences. Molecular Ecology Notes. 2007;7:965-8.

Wade P, Heide-Jørgensen MP, Shelden K, Barlow J, Carretta J, Durban J, et al. Acoustic detection and satellite-tracking leads to discovery of rare concentration of endangered North Pacific right whales. Biology Letters. 2006;2:417-9.

Wade PR, De Robertis A, Hough KR, Booth R, Kennedy A, LeDuc RG, et al. Rare detections of North Pacific right whales in the Gulf of Alaska, with observations of their potential prey. Endangered Species Research. 2011a;13:99-109.

Wade PR, Kennedy A, LeDuc R, Barlow J, Carretta J, Shelden K, et al. The world's smallest whale population? Biology Letters. 2011b;7:83-5.

Waite JM, Wynne K, Mellinger DK. Documented sighting of a North Pacific right whale in the Gulf of Alaska and post-sighting acoustic monitoring. Northwestern Naturalist. 2003;84:38-43.

Wildlife Conservation Society. Location of whale captures digitized from the Townsend whaling charts, [Original charts published in Townsend, C.H. 1935. The distribution of certain whales as shown by logbook records of american whaleships. Zoologica 19, No. 1:1-50, 4 charts]. New York: Wildlife Conservation Society; 2002.

Yoshida H, Yoshioka M, Shirakihara M, Chow S. Population structure of finless porpoises (Neophocaena phocaenoides) in coastal waters of Japan based on mitochondrial DNA sequences. Journal of Mammalogy. 2001;82:123-30.

\section{Submit your next manuscript to BioMed Central and we will help you at every step:}

- We accept pre-submission inquiries

- Our selector tool helps you to find the most relevant journal

- We provide round the clock customer support

- Convenient online submission

- Thorough peer review

- Inclusion in PubMed and all major indexing services

- Maximum visibility for your research

Submit your manuscript at www.biomedcentral.com/submit 